\title{
The Significance of Place in Urban Governance: Mart 125 and the Politics of Community Development in Harlem, New York
}

\author{
Dr. K. H. Mchunu \\ University of KwaZulu Natal \\ Dr. S. Mbatha \\ University of Stuttgart, Germany
}

Doi: $10.2478 / \mathrm{mjss}-2018-0030$

\begin{abstract}
The paper highlights the nexus between place and identity on the one hand, and urban entrepreneurialism on the other, which has become important nationally and internationally in recent decades. This refers to a form of urban governance that mixes together state with civil society and private interests to promote urban development. The city as a product of a common if perpetually changing and transitory urban life, "growth machines" or "urban regimes" play a significant role in the relationship between place and identity. This paper documents an instance of this relationship where the "growth machines" played themselves out in Harlem, New York City.
\end{abstract}

Keywords: Entrepreneurism; Growth Machine, Harlem, Urban Regime, Urban Governance

\section{Introduction}

The narrative about Mart 125 is familiar to most Black Harlemites. It is a story wrapped up with emotions of loss, powerlessness, marginalization, and missed opportunities. It is a story about the dynamic relations among the elected officials and their constituents involving access to resources, and the social impact of those warm, fuzzy, and blinding ephemeral bonds formed solely for the pursuit of material gains, without attention to the necessary oversights. It is a story about the significance of place, and the extent to which people develop an emotional identity with places and consequently a sense of ownership.

The Mart has been the subject of numerous video documentaries, numerous newspaper articles, and a discussion topic in different forums. Much discussion has been focused around the physical building and its significance to the community. Others have situated the discussions around the Mart within the broader economic globalization and its impact, gentrification being one of its manifestation as capital seeks more opportunities to invest (see for example Harvey 2012). In this paper, I weave the themes together for a more nuanced reading.

The paper presents the Mart 125 as an instance of the perceived and lived experiences and effects of the broader redevelopment processes currently underway in Harlem. It outlines the unprecedented pace and magnitude of the seemingly impersonal forces that are transforming the physical and social fabric of Harlem. For sale and to let signs are on every block and street in Harlem as the hood is goes through a gentrification process as Freeman (2006) noted. The Mart also provides an instance of the changing economic context and how cities and communities are adapting to this newly emerging and dynamic environment. In a sense, the paper presents an 
emotionally charged discussion about relationships (attachment) between people and places.

The paper takes the form of a narrative precisely because the story about the Mart has always been in the public domain. This contributes to keeping the story alive (as it still is) instead of some historical incident about a contested building in another city.

\section{Methods and Materials}

It was envisaged that data would be collected through a combination of secondary methods. This included consulting relevant books and journal publication around gentrification, newspaper clippings around Mart 125, and other available secondary material on the topic and gentrification in general. Direct observation in terms of physical changes to the structure was also an important part of gathering information. This included casual conversations in the community about the future and frustrations around Mart 125. The latter provided a source of inspiration for this project. Much time has passed since the closure and boarding up of this iconic building during which proposals have come and gone without anything tangible happening. Key individuals in the community and government have also move on physically and literally. This underscores the over-reliance on secondary sources of data for this project as primary sources proved challenging to track down for various reasons for possible interviews or questionnaires.

\section{Discussion}

\subsection{Mart 125: A Historical Overview}

Mart 125 is situated opposite the world famous Apollo Theater. It is an in-door city-owned market that was opened in 1986 with a $\$ 3.6 \mathrm{~m}$ sponsorship from the Harlem Urban Development Corporation (HUDC). The latter was the then Democratic party-controlled fiscal agent for reviving Harlem. The HUDC signed an agreement with the city to develop the Mart as far back as 1979 . The building took 8 years to build.

The Mart provided an economic opportunity to a growing number of street vendors that dotted the pavement along 125th Street. The building was a secured location within which to trade without the need to cart their wares back and forth from storage, and it also provided an environment to obtain the necessary expertise for running a successful business enterprise. It was therefore intended to provide street vendors with a legitimate arena for trading. According to Siegal (1998), the Mart was a collection of around 56 (some estimates have put the figure slightly higher) stalls trading in various goods.

The then relatively new phenomenon of informal street trading was on the rise in the nineteen eighties. The increasing number of mainly African street vendors along 125th Street elicited a need for public intervention of some kind by Mayor Koch's administration. According to Mr. Cogsville, President of Harlem Urban Development Corporation (HUDC), "Before the Mart, scores of unlicensed peddlers had set up in front of abandoned storefronts, clogging the sidewalks and making the stores unattractive to prospective tenants. The market eased the congestion and allowed the city to sell the abandoned stores". Although this was not the first time that the city had to intervene to address this concern, the Mart marked the first positive initiative by the city in trying to address this issue. The goal was for the Mart to act as a business support, with maturing businesses venturing out on their own. The government reportedly promised to provide training in management to vendors and a stake in the building with possibility for ownership (Williams 2008).

The building consisted of a single story of 10,050sq.-feet of space on the ground floor, a mezzanine floor of about 2,160sq.-feet, and a 5,120sq.-foot basement (Real Estate Weekly 2003). Between 50-60 merchants traded in a wide range of merchandise from Afro-centric goods, soul food, to music were housed inside the Mart. It was well situated at the heart of Harlem's main economic corridor, $125^{\text {th }}$ street, which is the focus of much recent economic activity in this newly discovered retail Mecca.

The Mart provided a one-stop-shopping center for mostly Black Harlem, from greasy fried chicken to an organic Juice Bar, from $\$ 2$ costumes to $\$ 400$ fine jewelry, from African-inspired cloths 
and artifacts. There was a bootleg music vendor, a bookshop, a bakery, and a beauty salon. All converged to make the Mart 125 a unique and unparalleled Black shopping experience, something unmatched before or since. According to then Borough President Virginia Fields, "it is a place where products that are distinct to Harlem can be displayed and sold". The then President of HUDC called the Mart a storehouse of culture that connects Harlem to the world by marketing goods from developing countries. "It ties into what Harlem is all about," he said. "Harlem is an international community." This is what made the Mart what it was, a microcosm of the diverse Harlem community.

All the elements were in place; the city as landlord and facilitator, independent administrator to manage the facility, eager tenants and patrons, a desirable location along Harlem's major economic corridor, and a conducive economic and political climate. Yet just fifteen years later in 2001 the building was boarded up amidst allegations of mismanagement, and unfulfilled promises between the tenants and management. Ironically, many of the intended beneficiaries of the Mart can be found along 125th Street where they began as street vendors where according to Tucker (2008) they have been subjected to 'rounds of police harassment, divide and conquer schemes, confiscation of goods and arrests.

The closure of Mart 125 elicited widespread community outcry and a rallying (see Tucker 2008) point against the process of gentrification (see Maurrasse 2006, and Freeman 2006), which was associated with the fate of Mart. Why was the closure of one building so significant to the locals? What were some of the elements that came together to conspire against the Mart? How do we make sense of this place and identity nexus? The view expressed here is that a number of factors coalesced, eventually culminating in the opening of the Mart in 1986 and its closure 15 years later in 2001. The following sections endeavor to unravel some of these questions as part of analysis.

\section{Analysis}

\subsection{The Inner City in a Nutshell}

The Mart as a project belongs to a different political milieu. It was a time when Harlem was more homogenous in terms of ethnic background and social status. Close to $60 \%$ of the total population of Harlem was classified as Black (Beveridge 2008). Since Harlem was also less desirable for private sector investment (red-lining), the state and local small businesses were by and large the sole forms of investment within the community. Elected officials provided much needed government social services in a long-standing reciprocal relationship involving votes for services with the Black community of Harlem.

During the turbulent nineteen sixties, from civil rights protests to worker's strikes, urban America and more specifically the inner cities were calling for change. The cities were burning and demands for African American autonomy and community control were increasing (Johnson 2004:3). For Black New Yorkers, fewer than 1000 owned their homes, and black businesses were routinely overcharged for rent (Maurrasse 2006).

There was also the issue of decades of under-investment (redlining), neglect by landlords and the government that exerted more pressure on the infrastructure of the inner cities, including housing. The crumbling infrastructure, coupled with high incidences of poverty, drug abuse, high unemployment, and other pathologies led to Wilson's (1987) isolated 'truly disadvantaged underclass' and designation of such areas as ghettos. Harlem fitted this description. No less significant were also the gains from the Civil Rights movement that had opened opportunities for middle class Blacks who, together with professional Black-owned businesses that served them subsequently left the inner cities. This contributed to the unprecedented spatial concentration of poverty in the inner cities.

In New York City, the ongoing fiscal crisis from the 1960's-80's, and the impact of Reaganomics soon after, meant that there were even less funds for services and other government programs that benefited the poor. In this vacuum, alternative forms of economic systems prevailed, which kept the community functioning (Maurrasse 2006:28). Politically, Black Power concepts were 
increasingly becoming more attractive to the African American community (Johnson 2004:12) with their message of empowerment and community control of resources.

The physical landscape of "the hood" was characterized by swathes of public housing blocks, the ubiquitous church buildings coupled with vacant lots right next to boarded-up buildings. The typical land use in-the-hood included a bodega on every corner, the obligatory hair salon, barbershop, cheque-cashing place, neighborhood-style liquor store with Plexi-glass, fast-food joints (Chinese or fried chicken), and a funeral parlor. Needless, all of this changed, replaced by boutique coffee shops and upscale restaurants.

Something had to be done to address the unfolding crisis in America's inner cities. Community Development Corporations (CDC's) like the Harlem Urban Development Corporation (HUDC) was established in 1972 to assist with the redevelopment of Harlem. Another focus fell on the youth, and this resulted in the establishment of Harlem Youth Opportunities Unlimited (HARYOU).

One of the projects HUDC funded was Mart 125. The significance of this fact cannot be overemphasized given the fact that red-ling continued well into the eighties when the Mart opened. Up until then the community relied mainly on local entrepreneurial activity there was and the inadequate but significant federal and city social services. The fact that the building was located within the community, at the heart of its economic nerve center was also significant. As a business incubator, the Mart formed one of the important cornerstones for community rebuilding and economic empowerment. The Mart was part of a larger and early revitalization project, the 125 Street Development, which includes construction and rehabilitation along this main thoroughfare of the area.

In a nutshell, the Mart was a product of this massive social ferment that acted as a catalyst for a variety of government initiatives aimed at inner-city redevelopment. The following section discusses the emergence of the HUDC and how this organization related to the establishment of Mart 125.

\section{The Harlem Urban Development Corporation: A Patronage Machine?}

The HUD was the original CDC that sponsored the formation of the Mart in the mid 80's. CDC's like the HUDC were meant to be tools that could effectively harness the "community's" scattered and limited assets, and transform them into an on-going tool for community empowerment (Johnson 2004:4). This emanated from the desire at Federal level to "do something" for the cities while at the same time respond to demands for community control (ibid).

The actual roots of the HUDC lies in Governor Nelson Rockefeller's attempts to position himself for a presidential run, his own gubernatorial reelection campaign, and his uneven relationship with New York City's Black political leaders (Johnson 2004:5). In 1964, Rockefeller proposed a new World Trade Center in lower Manhattan, and in 1966 through pressure from local (black) politicians, he promised to a smaller building uptown in Harlem. This compromise between Governor Rockefeller and the political elite of Harlem came about just as the Black Power Movement hit Harlem, only to undermine the already uneasy relationship by making the project their focal point of protest.

According to Zukin (2010), the community was suspicious of the Governor's motive for locating the state building at the heart of Harlem on 125th Street, which they regarded as a Republican attempt to channel white money into the community. Nothing short of outright community ownership of the land was acceptable to the community.

The ensuing protests and sit-ins prompted the governor to reassert the need for law and order and promptly removed the protesters from the site, and distanced his office from the project by creating the New York State Economic Development Corporation (EDC). The latter's mandate was basically to assist with redeveloping the slums. The EDC wasted no time in engaging in talks with the community for the establishment of a locally sponsored organization to guide the EDC (Johnson, 2004). The Harlem Urban Development Corporation (HUDC) came into being in order to act as a local subsidiary for the state EDC with a mandate to provide planning, feasibility studies, design, financing, construction supervision, and technical assistance to Harlem (Johnson, 2004).

From the onset, CDC's like HUDC played an ambiguous and seemingly contradictory role. On 
the one hand, they were attempts to work with and within the pre-existing economic and political structure. On the other hand, they were seen as a sort of a permanent opposition, a community's attempt to control its own destiny against "outsiders" (Ibid).

The relationship between EDC and HUDC lasted for a decade. By 1977, the HUDC had separated from the State Governor's office and was completely controlled by the Harlem Democratic Party political machine (Johnson 2004; Zukin: Op cit). The fact that the EDC was increasingly getting embroiled in political crises was fundamental to the breakdown of the relationship. The federal and state fiscal crisis in New York also affected EDC activities, all which meant that they could not exert the necessary oversight on HUDC and its activities. For the HUDC however, the imperatives of their funding requirements and the lack of additional outside sources pushed them from broader notions of economic development to more limited strategies of housing development (Johnson, 2004).

Johnson argues that the HUDC was part of the Harlem political machine and thus proved too useful to city and state politicians in the racial and ethnic political stew of New York state and city. HUDC and Harlem's Political Machine key to HUDC's untouchable status was the ascendancy of Congressman Rangel and the Harlem political elite in controlling the board of the HUDC... Rangel was an important source of behind the scenes control. Part of Rangel's power was his ability to secure federal funding commitments for HUDC....' (Johnson 2004:10). Black power, political competition in Harlem, electoral politics, and conflict avoidance all played a role in the creation of the HUDC (Ibid). All of this was to change significantly in the 90's. The evolution of urban politics and governance alluded to in the previous section suggests a dynamic shift away from the political landscape described above and in the previous section, which led to the establishment of HUDC and the Mart as one of its programs.

In 1994, the Clinton administration signed into law what is known as Empowerment Zone, assisted in no small measure by one of Harlem's political elite Congressman Rangel. The following year in 1995, Governor Pataki shut down HUDC and the Mart was taken over by the City. No sooner than Mayor Giuliani evicting the tenants by 2001, the Upper Manhattan Empowerment Zone (UMEZ) was established. The eviction happened in the midst of the Empowerment Zone and a wave of new investment in Harlem (Maurrasse 2006:73).

\section{6. "The Hood" as a Hip Place}

By the 1980's when the Mart was opened, Harlem had hardly experienced private investment in decades, the crack epidemic of the eighties was wreaking havoc in the community, and crime was rampant (Freeman 2006). Empty lots and boarded-up buildings galore.

But in the midst of this decline and degradation, other voices had already started (re) emerging in the inner cities. Civil rights organizations now coexisted with the Black Power Movements that put emphasis on Black-pride, race economic determination, and a Pan-African perspective on the African-American struggles. According to Johnson (2004:9) the rhetoric of black power and community control stepped into a breach that resulting from de facto "planned shrinkage" of the city through the withdrawal of basic city services from neighborhoods like Harlem that were judged to be unsalvageable. This reenergized groundswell of civic activism further cemented relationships between a succession of Democratic Party elected officials and their constituents. From Mayor Lindsay in the mid-sixties to Mayor Dinkins in early nineties, this relationship lasted until Governor Pataki and Mayor Giuliani; both Republicans, were elected into office in the mid-nineties.

The message of pride alluded to earlier was not only limited to self-pride, there was also a tremendous and new sense of pride about the ghetto as a place being, which strongly articulated in song, dance, and aesthetics. The ghetto was not only the source of 'inner-city blues', it was also the well-spring of all things modish. It is this pride of place, the economic vacuum created by the lack of investment, the politics of patronage between community and elected officials, and the spirit of economic self-determination that coalesced and contributed to the formation of the Mart 125th. The Mart symbolized a new zeitgeist in Harlem.

However, this emotional attachment to place was to prove inadequate to determine the 
nature and direction of future development in the neighborhood. The Mart illustrates the extent to which people identify with certain places, which in turn engenders a sense of ownership in the absence of concrete steps toward real ownership. Emotional identity with places is not enough. The arguably justified sense of entitlement to Harlem could also emanate from the feeling that these people kept the home fires burning while the middle class skipped town, the private sector engaged in red-lining, absentee landlords neglected their buildings, and successive government policies failed to address the plight of the inner-cities. They alone made Harlem what it is by sticking it out through all the trials and tribulations (Maurrasse Ibid: 43).

The Mart was emblematic of the extent to which the wider community was not in control of resources within the neighborhood. For example the current gentrification process is largely driven by economic forces outside the community with a handful of local real estate agents and developers benefiting. This lack of outright ownership was always going to undermine any endeavor at real community empowerment. Just like the rest of Harlem where the majority of vacant lots, boarded-up buildings and housing stock were either government owned or in private ownership, both of which are outside the community, the Mart also suffered from a similar fate in terms of lack of ownership by the community.

It is however ironic that much of the change in Harlem was precipitated by resident's civic engagement, which attracted not only new resources into the area but also attention to the neighborhood (Ibid: 171) as a place not only to live and also do business, much of it to their detriment. One reason could be that people did not engage in a lot of organized activities in a constructive wasy to really demand accountability from the public and private sector and their institutions as Maurrasse tries to point out. The community was not really consulted about what type of changes they would want to see, hence the prevailing dismay about the redevelopment process (see Freeman 2006; Sharman 2006; Zukin 2010; Maurrasse, 2006 among others). Another factor has to do with lived experience of decades of discrimination and neglect by government agencies and private corporations, which have generated a deep sense of caution and lack of trust for outsiders in the community.

\section{From Zenith to Nadir; the Closure of the Mart}

"they talk about empowerment. Here's an example of empowerment." Mr. Coy M. LaSiste, La Soeur Management and Development Company

Since the building closed in 2001 , it has been the subject of at least one documentary film, a focus of numerous newspaper articles, and an emotionally charged topic of discussion on the streets of Harlem along with gentrification, which they regard as a synonym for what transpired with the Mart 125. But the closure of the Mart resulted from 4 key elements: poor maintenance and misadministration, a changing broad social and economic context, and realignment in the political landscape.

The Mart operated for almost fifteen years before suffering from a set of misfortunes. Allegations of mismanagement and poor administration began surfacing with $\$ 100 \mathrm{~m}$ spent in two decades. After eight years of building, and even then still incomplete, the merchants moved in nevertheless (Waldman, 2001). The promise that tenants would be trained and eventually own the Mart was not kept; the roof leaked; garbage piled up; the air conditioning failed, and operating expenses estimated at $\$ 400000$ at the time of closure (ibid). The lack of necessary maintenance and repairs took their toll on the physical structure. Some vendors refused to pay rent for what was perceived to be poor services on the part of the administrators. When the City took over the Mart in 1996, only 2 vendors were paying rent. Vendors had to also cope with overcapitalization costs. According to La Soeur Management and Development Company, the average rent at the Mart was $\$ 100$ per square foot compared to average commercial rent elsewhere on 125th Street at $\$ 40-\$ 60$ per square foot at that time, and renovation cost were estimated at $\$ 800,000$.

Politically, the Republicans were becoming ensconced in City Hall. The Harlem Community Development Corporation (HCDC), which had replaced the Democratic Party controlled HUDC, was dominated by Pataki appointees (Johnson, 2004). The Upper Manhattan Empowerment Zone (UMEZ) formed in 2001, reflected a strong bias in favor of Republicans in terms of its leadership 
and funding priorities. The relations between Harlem's elected officials and the Republican Mayor were also strained as they tried unsuccessfully to intervene on behalf of the merchants (Waldman, 2001). Generally, suspicion of political motivations between Democrats and Republicans were omnipresent.

There was also the inherent structure of CDC's to contend with. Their ability to engage in activities other than housing production and some limited commercial activity was virtually an impossible goal to achieve from the very beginning (Johnson 2004:5). For the HUDC in particular, control by the political elite of Harlem, general mistrust of outsiders, and allegations of mismanagement all served to undermine its potential to fulfill its mandate.

Finally there was the changing economic context in favor of markets and the emerging shift towards culture and leisure industries as new strategies for economic development. This forced a shift in terms of funding and investment priorities for cities, and inevitably the realignment in local politics in line with this emerging reality.

The Mart also suffered from the lack of visionary leadership in the terms of appreciating the unique circumstances that coalesced to make it possible. The tumultuous energy of the sixties that bequeathed among others, a unique set of relationships between local officials and their constituents; the black conscious message of racial pride and the need for community selfdetermination; and the conditions that led to the creation of HUDC as initial funding agency. This opportunity was not seized to the advancement of intended beneficiaries, the majority of who reverted back to the street as vendors.

The significance of the Mart as an opportunity for economic advancement is evident from statements by local politicians. Ms. Velasco, spokeswoman for Councilwoman Inez Dickens said the "Mart 125 was very, very important to the councilwoman from a historic perspective because it was a place originally designed for minority vendors and artisans to sell their goods. The councilwoman wanted what will replace Mart 125 to be a place where community people would be stakeholders." According to Waldman (2001), Councilman Bill Perkins said the Mart is "pregnant with symbolism of the modern history of Harlem." It first represented an attempt to keep economic activity alive in the neighborhood's darkest moment ....and reflects the effort to keep a place for small black businesses in a rapidly transforming Harlem.

Mart 125 Merchants Association, which represented many of the vendors made an appeal before Community Board 10 soliciting support to form a tenant cooperative to buy the Mart from the city. Emotional appeal alone is no substitute for lack of a viable plan, financial wherewithal, and political clout. The old narrative of local economic development through empowerment was slowly giving way to a more private sector, market driven approach introduced by the Clinton administration through the Empowerment Zone legislation in 1994. Allegiances had shifted in the face of the new economic and socio- political realities of the mid-nineties. Markets were becoming more and more entrenched and 'the hood' was not immune to their reach; new incentives were being introduced to entice private sector investment into inner city neighborhoods like Harlem; the gentrification process was and continue to diluting the social makeup of Harlem with young professionals of every hue, while at the same time altering the physical fabric of the place as new condominiums and apartment blocks emerge all over Harlem to cater to this new market; Housing programs like HOPE VI are decentralizing poverty through mixed-income development by moving inner city residents out of 'the hood'.

How do we make sense of this change and how does this relate to the closure of the Mart? What type of physical landscape is emerging and how does this relate to the social fabric of the community?

\section{Emergence of New Urban Economies}

Gospondini (2006:19) argued that postmodern urban societies are increasingly witnessing a new interrelated socio-spatial phenomenon, such as a rapid evolution of urban politics and governance from traditional managerial forms to more entrepreneurial forms - as well as the emergence of radically new models of urban politics and governance focused on amenity.

According to this view, cities have to offer inducements to capital either by refashioning their 
economic attractiveness (tax abatements) or by amendments in their soft infrastructure. Improvements in the latter mainly involve the development of creative cultural and leisure amenities and enhancement of the city's image through landscape transformation (Ibid: 19).

These societies are also characterized by high mobility of an increasingly middle class of young professionals mainly courted by cities competing for them with urban amenities.

A number of shifts took place in New York State and City that signaled a change in direction in city politics and economy. Politically, Governor Pataki and Mayor Giuliani, both republicans, were elected into office. The new Governor wasted no time in shutting down the HUDC. Mayor Giuliani also closed the Mart in 2001, which was ironic because as a business incubator it fitted with the new economic regime being introduced. Economically, President Clinton signed into law the Empowerment Zone in 1994. The combined effects of these changes was that priorities shifted from social welfare to 'making markets' (Zukin 2010), a process which was initiated by President Reagan back in the mid 80's through rolling back of welfare in favor of the markets.

The physical landscape is also going through an arguably unprecedented process of transformation. The design of the new structures has been criticized for being out of sync with the neighborhood, with no Harlem flavor, for not fitting in, and being insensitive to the preexisting culture and style of the neighborhood (Maurrasse 2006:123).

Notwithstanding the lack of consultation and general resentment about the regeneration process alluded to earlier, what we are witnessing is the emergence of what Gospodini refers to as 'glocalised landscapes'. This refers to an emerging landscape collage dominated by tradition with local spatial references and innovation having more universal appeal (ibid:29). For example new structures such as Harlem USA and the revived Apollo Theatre coexist in this postmodern hood landscape.

Cultural and built environment heritage have become essential elements of the new economy based on cultural and leisure industries. Urban economic development strategies now put emphasis on enhancing and promoting unique qualities of place in an endeavor to create and advertise them as brands. Urban design is an essential element in this branding exercise as regeneration with emphasis on spaces for leisure, cultural, and consumption. Instead of being an outcome of economic growth, urban design is also increasingly becoming a tool for promoting economic development. According Gospodini, culture is now seen as the magic substitute for all the local factories and warehouses, and as a device that will create a new urban image making the city more attractive to mobile capital and professional workers (ibid:29). The regeneration currently underway in Harlem is largely driven by external forces as a new frontier for investment. Both style and pace of development seem out of sync with existing building stock and demand respectively as exhibited by a plethora of advertisements for vacant new residential and office/retail spaces.

In New York City, Harlem is second to the statue of Liberty as a tourist destination with $1.4 \mathrm{~m}$ visitors per year, who spend over $\$ 25 \mathrm{~m}$. This translates to an impact of over $\$ 154 \mathrm{~m}$ to New York City and over \$4m in tax revenues (Maurrasse, Op Cit: 32-33). UMEZ has replaced HUDC as the main catalyst for the redevelopment of Harlem and there has also been a shift in funding priorities in favor of entrepreneurial as opposed to social services (Zukin: Op Cit). The NYCEDC together with the Department of Cultural Affairs have also emerged as important allies in the emergence of this new economy. After the building lay dormant since 2001, the proposed redevelopment of the Mart suggests the building was not immune to these new developments.

The nature of the redevelopment proposals reflects this cultural turn and focus on leisure as reflected in RFP's and subsequent choice of tenants. Both the Jazz Museum of Harlem and Imagenation as main anchor tenants correspond to and represent a major shift in local economic development thinking and strategy. This discussion now turns to the new Mart and how it fits in with the regeneration currently taking place and the cultural turn in local economic development.

\section{The New Mart}

"I would like to see Mart 125 have some remnant of what it was originally slated to be - an incubator for vendors. I would like to see some retail with some community folks able to make some money." Assemblyman Mr. K. Wright 
"The idea is to help black folks own something in this community," Mr. Coy M. LaSister, VP for 100 Black Men and President of La Soeur Management and Development

Notwithstanding the discussed problems around the closure of the Mart, there were other significant factors at play. The new emphasis on the combination of culture and leisure as tools for economic development suggested that if the Mart was to be revived, the new Mart had to reflect this new thinking and focus. The choice of Imagenation and Jazz Museum of Harlem provide a hint at a Black Cultural Precinct of sorts along with the proposed African Square under the State Building, Apollo Theatre nearby, the Studio Museum of Harlem, and the revival of the Oxford Theatre.

Proposals for the new Mart include a mixed use development with up to 67,000 square feet for cultural and commercial uses (NYCEDC, 2010). According to officials, the developer is to work with one or more of the arts groups on a joint proposal. The plan's unusual mandate for a developer to include a cultural group with local ties may be testament to the lingering symbolic importance of Mart 125 among Harlem residents.

The proposed $\$ 4.4$ million project was expected to create about 40 construction and 75 permanent jobs (Columbia Spectator, 2009). Jazz Museum of Harlem plans to use the space for offices, exhibitions, performances, and a listening library (Real Estate Weekly, 2003). ImageNation hopes to offer a packed calendar of films, live music, and spoken word events, along with tasty concession snacks such as Pan-African tapas and traditional soul food (Columbia Spectator, 2009).

In a nutshell, the new proposals for the Mart are more in keeping with this creation of a new terrain for experiencing new forms of spaces with emphasis on a combination of leisure and culture as driving forces (Gospodini, 2004). Starbucks, Applebees, Modell's, Magic Theatres, the Apollo Theatre, Studio Museum of Harlem, Harlem USA, the new condominiums, and the new Mart, and all come together in Harlem as the cycle of development and redevelopment plays itself out.

\section{Conclusion}

The discussion has tried to establish the significance of the Mart as an instance of community economic empowerment at a specific moment in the history of Harlem. An attempt was also made at relating the story about the Mart to the broader narrative concerning the regeneration process currently underway in Harlem.

The main thrust of the argument presented was that the Mart represented an instance of a missed opportunity at community economic empowerment. The unique circumstances that led to the establishment of the Mart may no longer be obtainable and sustainable given the existing political, social, and economic landscape.

Politically, the city and state were in the hands of Republican officials. Economically, the idea of 'making markets' and cutting on social services was gaining more traction in society.

Harlem is also increasingly becoming less homogenous as a community. These factors combined to seal the fate of the Mart and its main sponsor the HUDC. There are two pertinent observations emerge from this overview. First is the importance of establishing a real stake in the community such that any positive developments in the area benefit the larger community, particularly those directly involved. There should be accountability measures established and proper oversight mechanisms put in place so that promises to vendors for training and stake in the building could be followed up accordingly.

The lack of outright ownership of the building by the community was fundamental to the success of the Mart as an empowerment project. This may not have been sufficient to guarantee the sustainability of the project without necessary training and support mechanism. At least ownership would have guaranteed that the facility remained in the hands of the community to determine its fate. The Black Power movement has long recognized the importance of community ownership of resources as a basis for community development and empowerment. The HUDC was welcomed precisely because it promised to locate ownership of resources within the community.

But the limit to the success of the Mart success was embedded in the manner in which the same deal was structured in terms of financing and ownership.

Secondly, in relation to the redevelopment process that is taking place in Harlem, the issue of 
ownership comes up again, which is more important than just mere prolonged physical presence in the area. This calls for vigorous community organizing and solidarity that informed the movements of the 60's with adaptations to fit the current context.

Finally, Initiatives such as The Harlem Children Zone's Community Pride augur well or the future of Harlem. Established in 1992, the program organizes tenant and block associations, helping them to convert city-owned buildings into tenant-owned co-ops.

\section{References}

Beveridge, A. A. (2008). A Century of Harlem in New York City: Some Notes on Migration, Consolidation, Segregation, and Recent Development. City and Community, 358-365.

Columbia Spectactor. (2009, 11 8). Retrieved from Columbia Spectator: http://columbiaspectator.com/2009/11/08/nonprofits-move-ahead-mart-125-redevelopment

Freeman, L. (2006). There Goes The 'Hood: Views of Gentrification from the Ground Up. Temple University Press.

Gospodini, A. (2006). Portraying, classifying and understanding the emerging landscape in the post-industrial city. Cities.

Gospondini, A. (2004). Urban Morphology and place identity in European cities: Built heritage and innovative design. Journal of Urban Design.

Harvey, D. (2012). Rebel Cities: From The Right To The City To The Urban Revolution. New York: Verso Books.

Johnson, K. (2004). Community Development Corporations, Participation and Accountability: The Harlem Urban Development Corporation and the Bedford Stuyvesant Restoration Corporation. Annals of the American Academy of Political and Social Science 504, 109-124.

Maurrasse, D. J. (2006). Listening to Harlem: Gentrification, Community, and Business. Routledge.

NYCEDC. (2010, May 25). Retrieved from NYCEDC: http://www.nyced.com/press-release/new-york-cityeconomic-development-corporation-seeks-developer-mart-125-site-harlem

Real Estate Weekly. (2003, December 3). Developer Chosen for $\$ 4,4 \mathrm{~m}$ Harlem project (Harlem LLC has been selected to redevelop Merchandise Mar. Real Estate Weekly.

Sharman, R. L. (2006). Tenants of East Harlem. University of California Press.

Siegal, N. (1998, October 18). Retrieved August 19, 2014, from New York Times Web site: http://www.nytimes.com/1998/10/18/nyregion/neighborhood-report-harlem-on-to-hopes-for-mart-125.html

Tucker, M. L. (2008, April 15). Retrieved from https://www.villagevoice.com/2008/04/15/harlem-vendors-protest125th-street-rezoning/

Vendors Angry at evictions from city mall in Harlem. (Metropolitan desk). (2001, August 16). The New York Times.

Waldman, A. (2001, August 16). Vendors angry at evictions from city hall in Harlem (Metropolitan Desk). The New York Times.

Williams, T. (2008, August 2). In Plans for vacant Harlem Market, City Envisions a cultural base. New York Times.

Wilson, W. J. (1987). The Truly Disadvantaged: The Inner City, the Underclass, and Public Policy. University of Chicago Press.

Zukin, S. (2010). Naked City: The Death and Life of Authentic Urban Places. Oxford: Oxford University Press. 